\title{
Comparative social rights: status and integration in the US
}

\author{
Luis Ricardo Fraga ${ }^{1}$ Bryan Wilcox-Archuleta ${ }^{2}$
}

Received: 9 December 2017 / Accepted: 15 February 2018 / Published online: 25 June 2018 (C) Springer Nature Singapore Pte Ltd. 2018

\begin{abstract}
In this essay we develop a framework for better understanding how a focus on enhancing the social rights of immigrants and migrants can lead to greater levels of social incorporation for these groups into their destination countries and/ or communities. First, we discuss how the concepts of social rights and incorporation have been used in the social sciences to understand migrants and immigrants. Second, we critically discuss models of immigrant incorporation derived from studies of the US and Europe to demonstrate the value of developing comparative frameworks across distinct countries and communities. Third, we develop and apply the categories of status and integration to discuss how social rights derived from public policy can serve to inhibit or facilitate the effective incorporation of immigrants and migrants. Fourth, we describe how subnational, state-level governments have become increasingly critical actors in affecting both status and integration in the United States. We demonstrate that social rights and incorporation cannot be understood in the US today without an appreciation for variation across distinct state governments. Lastly, we conclude with a consideration of how our analysis makes very clear that government officials are in key positions to determine the scope and depth of immigrant and migrant social rights and incorporation in ways that can simultaneously serve the long-term interests of immigrants, migrants, and the nation state as a whole.
\end{abstract}

Keywords Social rights $\cdot$ Incorporation $\cdot$ Immigrant $\cdot$ Migrant $\cdot$ Status · Integration $\cdot$ United States $\cdot$ States $\cdot$ Nation-state

Luis Ricardo Fraga

lfraga@nd.edu

1 University of Notre Dame, Notre Dame, USA

2 University of California Los Angeles, Los Angeles, USA 


\section{Introduction}

The successful incorporation of immigrants and migrants within the social, economic, and political fabric of the nation-state brings many benefits to these individuals, local communities, and to the nation-state itself. Immigrants and migrants benefit from the increased opportunities incorporation can provide that facilitates upward social mobility, increased earnings allowing workers to better provide for their families, and greater individual identification with and respect for the state. Local communities, whether neighborhoods, towns, cities, and/or counties benefit directly from the greater predictability of patterns of population growth, job gains, and citizen satisfaction that can serve to facilitate necessary short and especially long-range planning at these levels of local governance. States, provinces, and national governments unquestionably benefit from increased incorporation through enhanced social stability, increased capacity for regional and national economic growth, and the increased favorable identity and satisfaction of citizens and residents with state, provincial, and national governments.

If the above-described benefits are clear and serve so many individual, community, and governmental interests simultaneously, why is it that the United States and many other countries, including China, have such mixed and uneven policy commitment, alignment, and coordination with regard to the effective incorporation of so many of their immigrants and migrants? The goal of this essay is to better understand this disjunction between interests and policy consequences.

Our essay begins with a discussion of social rights and incorporation. We will focus on various ways that both concepts are defined, have been applied in social science literature, and how policies and practices at national and state/provincial governments have had an impact on each. Although we doubt that it is possible for scholars and government officials to come to agreement on common definitions, we do think that such a discussion can help inform residents, citizens, and especially government officials as to the likely consequences of utilizing distinct characterizations of social rights and incorporation in their pursuit and implementation of polices related to immigrants and migrants. Second, we then move to a discussion of two recent models of incorporation that attempt to specify the primary factors that are likely to affect the rates and depth of incorporation of immigrants, with implications for the study of migrants. We will highlight attempts by scholars to offer analytical frameworks that take into account the substantial variation that can exist across nation-states, as well as the increasing reality that at times there can be as much variation within one nation-state in both policy and practice as there are across nation states.

Third, we discuss the need for analysts and scholars to distinguish between two critical dimensions of policies and practices that directly determine levels of incorporation. These two dimensions are status and integration. Without a doubt these two dimensions are related and intersecting, however, by distinguishing between them, we are in a much better position to strategize as to how policies and practices may need to be modified to promote greater incorporation. Fourth, we provide an assessment of recent policies and practices in the United States regarding 
immigrant status and integration with direct implications for incorporation. The important distinction we make in this part of the essay is between national and state levels of government. The US national government has been unable to develop the majority consensus necessary to enact legislation regarding substantial immigration reform. Nonetheless, President Obama undertook executive action to address some fundamental issues of incorporation. Moreover, since the mid-2000s there has been an explosion of state-levels laws and related actions that have specifically focused on immigrant incorporation. What has been the nature of these laws and are they focused largely on promoting or limiting status and integration? Lastly, we conclude with a consideration of the consequences for immigrants, communities, and governments of accepting limited incorporation as a reality of current policy and practice that are resistant to change and argue that such policies are unlikely to serve the long-term interests of each. We draw out implications that we apply to a number of nation states, including China.

\section{Social rights and incorporation}

We define social rights as the governmentally authorized guarantees that immigrants and migrants, whether citizens or residents, have in their choice of employment, housing, health care, education, and civic engagement. We understand these guarantees to be fundamental to a person's capacity to live with dignity and to have a reasonable chance of providing for their family. Except for those who are unable to work, such as very young children and those with disabilities, gainful employment is the foundation of any person's capacity to have sufficient material resources to live. Although the wages gained from work vary according to tradition and the labor market, having enough money to secure housing, health care, and educational opportunities for one's children becomes virtually impossible without formal recognition of social rights.

In the case of the United States and some other countries, one can also add choice in expression and substance in demands upon the nation-state, as well as competitive choice in the election of political leaders, as among the fundamental social rights that can be made available or denied to immigrants and migrants. Demand-making and voting are understood as fundamental to social rights because the specific laws and related policies pursued by government at all levels set important parameters that define the context within which citizens and residents are able to pursue employment, housing, health care, and education. For example, legal practices pursued by employers in the selection and treatment of their workers, the discretion that public and private actors have to determine which housing is available, determinations of what type of health care is available and who will pay for it, as well as school eligibility, attendance, and cost all occur largely within the context of public laws and policies made by government officials. Choice in expression and substance of demands, as well as in the election of political leaders can allow for feedback from citizens and residents in assessing how these laws and policies affect their lives. This assessment can be supportive or critical of governmental decisions. This 
can be understood to establish a feedback loop that can serve to assist the nationstate in meeting the needs of its citizens and residents.

It is also important to understand that there can be wide variation in the types and depth of social rights that a nation-state can choose to provide. Relatedly, there can be considerable variation across countries as to the minimum threshold of social rights.

Incorporation is defined as the extent to which immigrants and migrants, whether citizens or residents, are able to realize identified social rights in their daily lives. We also distinguish between social incorporation and political incorporation. Social incorporation is understood to include the access that immigrants and migrants have regarding employment, housing, health care, and education (Alba and Nee 2005; Bloemraad 2006; García-Castañon 2013; Telles 2010; Itzigsohn and Giorguli-Saucedo 2005). Political incorporation refers to the presence and effectives of demand-making upon the state as well as the extent to which immigrants and migrants have choice in casting their votes for government leaders (DeSipio 2011; Freeman 2004; García-Castañon 2013; Lee et al. 2006). There can be a considerable difference between the social rights that are established in law and the rights that are lived by these individuals. This distance between formality and reality is often determined by which enforcement mechanisms and practices the government pursues in exercising its oversight responsibilities for establishing social rights.

As suggested by the above definition, there are many measures of social incorporation. Rates, types, and stability of employment are common measures that nationstates use to gauge the access of its citizens and residents to opportunities for work. Equally important can be the treatment of workers and the related working conditions of those who are employed. Availability, quality, and cost of housing are also common measures used to assess the living conditions of citizens and residents. Birth rates, death rates, chronic illness, and availability of quality medical care are also often used to gauge the access to health care of a nation's population. The availability and quality of education for children and youth as well as their graduation rates from secondary school are often used to gauge degrees of social incorporation. Given the importance of advanced education in gaining employment in growth sectors of economies such as high tech, engineering, information processing, and many other areas of what is sometimes called the knowledge economy, the availability of postsecondary or higher education and the graduation rates of immigrants and migrants from related educational institutions can also give considerable guidance for understanding the extent to which a group has achieved social incorporation.

Political incorporation is defined as the extent to which "self-identified group interests are articulated, represented, and met in public policymaking" (Ramírez and Fraga 2008, 64). There are three specific dimensions to formal political incorporation within the context of the United States. First is the electoral dimension. This is the component that specifies the capacity of identified groups to participate in open, competitive elections to choose officials for public office. The second dimension is representational. This factor identifies the extent to which a group's first choice candidates are successfully elected to formal office. The officials are chosen with the support of specific group(s) of voters and it is understood that they will, to the best of their ability, articulate and advocate for the material, value, and broader policy 
interests of groups who supported them as a way of further solidifying support from distinct segments of their constituency. The third dimension of formal political incorporation directly relates to what is termed in the literature as policy-gain. This dimension specifies the extent to which those material, value, and broader interests of subsets of citizens and residents are actually met in public policy that is enacted by government. Policy-gain leads to the effective bonding of segments of the electorate to the nation-state because they see that their support for specific elected leaders leads to direct benefits in line with their desired states of affairs.

It is evident that social incorporation and political incorporation can be interactive and mutually dependent. Greater social incorporation can lead to a segment of the population having greater financial capacity to secure goods in the economy and also have sufficient social capital, such as knowledge, information, and interpersonal networks, to participate effectively in elections and policy advocacy. Policygain resulting from greater political incorporation that is consistently secured by a group, such as through enhanced funding for schools that serve a specific segment of the population, can then lead to increased chances to attend more selective universities which then leads to individuals from that group having greater chances at higher-pay employment. This can then lead to higher levels of social incorporation. It is this interactive effect of social and political incorporation that helps us better understand the critical role that governmental officials have in pursuing more, as compared to less, comprehensive approaches to both the social and political incorporation of immigrants and migrants. We well appreciate that the above discussion should be modified to specific national histories, party systems, and governmental structures, which can facilitate cross-national comparisons. We argue, however, that these differences are more relevant for specifying the distinct processes that may need to be followed to increase the social and political incorporation of immigrants and migrants. Nonetheless, the importance of developing policies that simultaneously promote both social and political incorporation can serve the interests of many nation-states.

\section{Models of social and political incorporation}

Marrow (2011) presents a useful characterization of the immigrant experiences in the United States that helps us to further understand the processes underlying paths of social incorporation. She develops a model that focuses on what she terms a "context of reception" approach that is common in the literature on the sociology of immigration in the US. As Marrow states, elements of this model were first developed by Alejandro Portes and his co-authors in a number of essays (Portes and Bach 1985; Portes and Borocz 1989; Portes and Rumbaut 2006). Consistent with much of our previous discussion, the context of reception "emphasizes how the structural and cultural features of the specific contexts that immigrants enter influence their experiences and opportunities for mobility, above and beyond the role played by their own individual characteristics and motivations" (Marrow 2011,9). She continues that there are four components of the context of reception that are most significant in affecting the social integration 


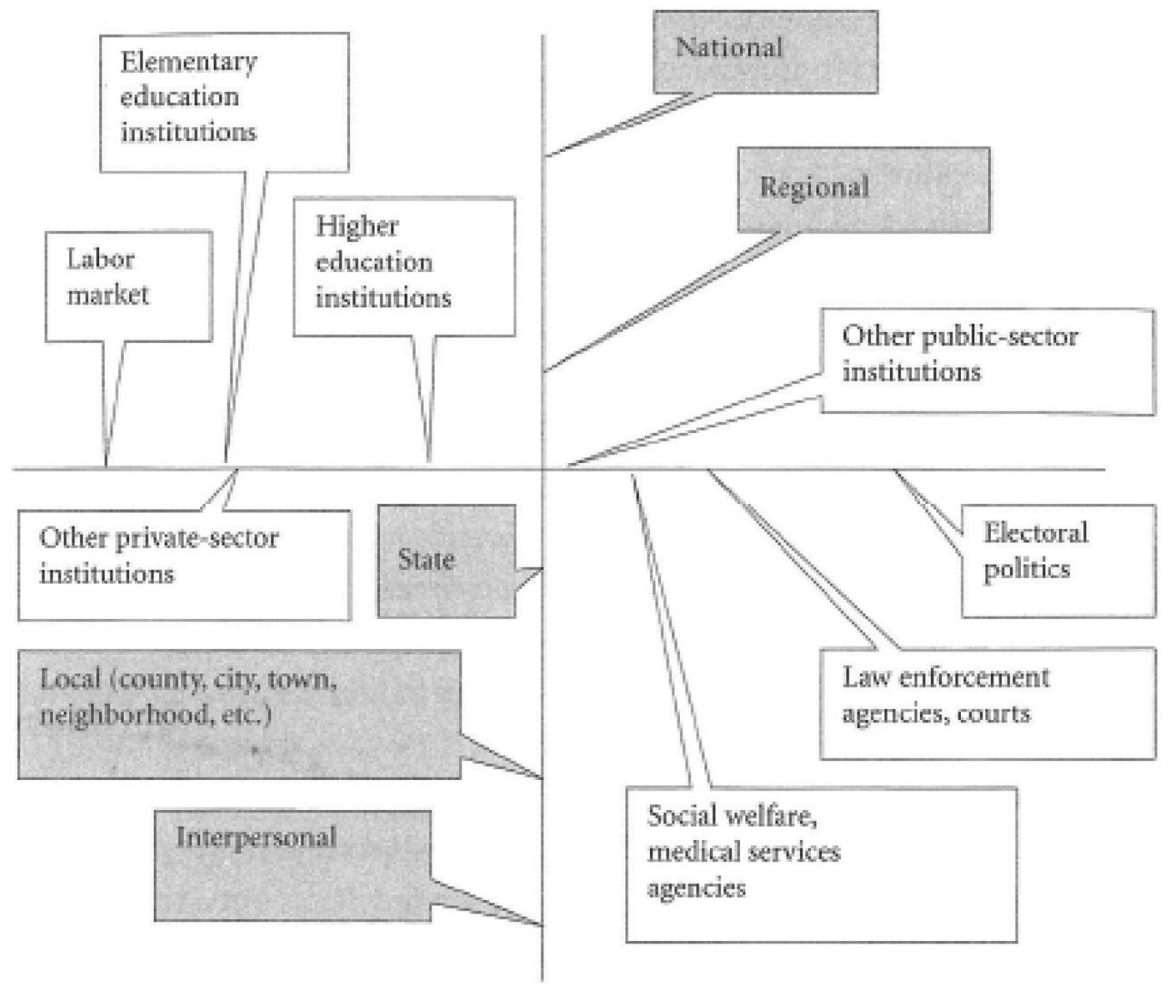

Fig. 1 Multiple dimensions of contexts of reception. Marrow $(2011,234)$

of immigrants and subsequent generations. They are: "the policies of the receiving government, the conditions of the receiving labor market, the characteristics of the newcomers' own receiving ethnic communities, and the reactions of receiving non-ethnic communities" (Ibid). This model is presented as Fig. 1.

The vertical dimension of this model of social incorporation captures the major actors that affect the life chances of immigrants that largely result from formal governmental policy. She notes that there can be both similarities and differences between the receptiveness to immigrants articulated in policy at national, regional, state, and local policies. She also notes that these policies can be accepted or not by individual residents who are not immigrants. The horizontal dimension of the model captures the context of reception driven by policies and practices of social institutions such as schools and universities, social welfare and medical services agencies, law enforcement agencies and courts, electoral structures, and other private and public institutions.

What is insightful about Marrow's model is that in identifying the primary governmental and other actors whose policies and practices can directly affect the chances of social incorporation, she notes how these actions can be mutually supportive of an overall policy goal of enhanced incorporation, limited incorporation, 


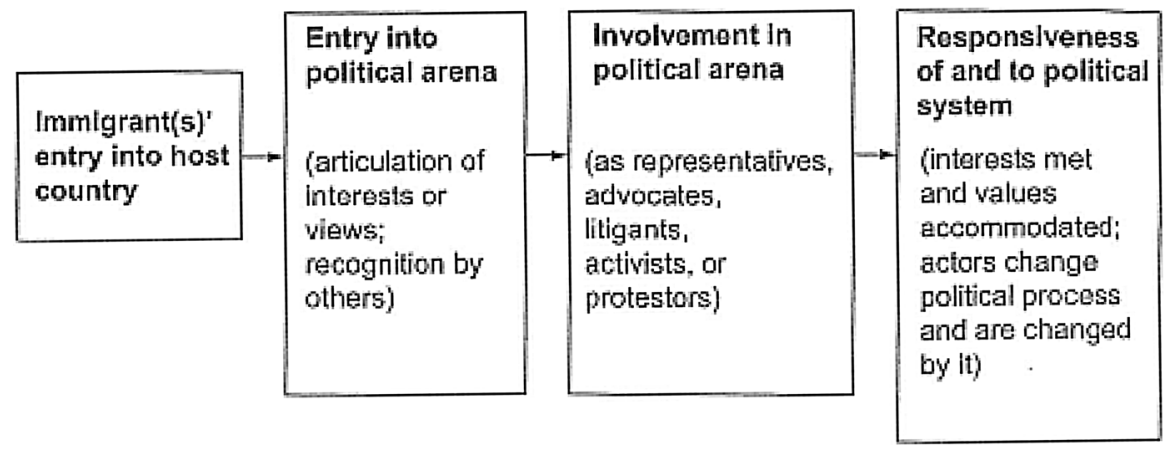

Fig. 2 Basic model of successful immigrant political incorporation

or can be in contradiction with one another across these different levels of government and related actors. We will, in fact, return to these national v. state distinctions later in the essay. Marrow's framework also allows us to appreciate that the path to social incorporation is complex, interdependent, and, at times, even contradictory. Linear progress is not apparent in many immigrant communities in the US today. Finally, Marrow appropriately positions the immigrant as a critical actor within the process of social incorporation, but the immigrant's chances of success are substantially structured by the actions of social and political institutions over which they have relatively little control.

Hochschild and Mollenkopf (2009) offer a model that is focused specifically on the political incorporation of immigrant groups in Western Europe and the United States. This model is presented in Fig. 2. They characterize political incorporation as "(1) a process (2) for individuals or groups (3) encompassing views as well as interests (4) involving various forms of political activity, and (5) including changes caused by as well as changes to immigrants' political activity" (2009). Their model has four primary components: entry into the host country, entry or non-entry into the political arena, involvement or non-involvement in the political arena, and responsiveness or non-responsiveness of and to the political system (Hochschild and Mollenkopf 2009, 11).

This model of political incorporation synthesizes elements of our previous discussion in ways that facilitate some cross-national comparisons. Understanding that entry, involvement, and responsiveness are foundational stages which all immigrants confront helps us to specify the unique ways that these appear in countries with varying histories, governmental structures, and opportunities for engagement designed to influence policy decision-making. Their model also reinforces our earlier claim that although cumulative progress is certainly possible, there are definitely no guarantees of incorporation over the long-term. They also help us to conceptualize the distinct ways that progress in political incorporation can occur by noting the utility of Zolberg and Woon (1999) distinction between progress that occurs through "individual boundary crossing", "boundary blurring", and "boundary shifting", (Hochschild and Mollenkopf 2009, 28-29). These different avenues of incorporation allow us to distinguish between incorporation achieved by individuals as compared 
to groups, and also distinguish between short-term and longer-term progress toward political incorporation.

What these two models help us further understand is that, as previously stated, social and political incorporation can be highly interdependent and exist within the complex realities of immigrant experiences in host countries. Each nation has its own path to development and the balance between social and political incorporation is likely to vary depending on a nation's specific history and current political structures. No one model can capture the full experiences of every nation or serve as a prescription for how any one nation should attempt to attain incorporation. However, these models do help us focus our attention on specifying critical dimensions of analysis of immigrant and migrant experiences that can facilitate cross-national comparisons to broaden the range of choices that governmental leaders have to adapt lessons from other countries to their specific national histories, as well as their social and political structures.

\section{Status and integration}

To facilitate comparisons between the US and China, we focus on specifying distinct policies and practices in the US regarding immigrant and migrant status and integration that are critical to understanding their paths toward both social and political incorporation. Status refers to policies that directly affect the formal legal standing of immigrants and migrants in a host country or community. These policies provide the formal parameters that set the context for reception for these groups by outlining the framework within which a wide variety of public and private actors might choose to respond to immigrants and migrants, justify the treatment of these groups, and certainly provide the guidelines to those government officials responsible for enforcing laws related to violations of immigration or migration status. Among these policies are:

- Policies that determine the legal standing of immigrants and migrants regarding residency in their destinations, e.g., laws in the US that determine who is eligible to be authorized to move to the United States for extended or temporary periods of time;

- Policies that determine the legal standing of family members of immigrants and migrants regarding residency in their destinations, e.g., family reunification policies in the US for those who have spouses/partners, children, parents, or other family members in the sending country or community;

- Policies that determine the punishment for being in the destination country or area without proper authorized residential standing, e.g., deportation policies and practices in the US that can separate parents from children, even if the children are full citizens of the US.

It is important to recognize that status can vary significantly across individuals and groups. There is rarely just one status granted to all immigrants and migrants. In fact, these variations tell us much about the goals of governmental policy regarding 
immigrant and migrants. For example, variations in individual and groups statuses in social and political incorporation can specify who is favored and disfavored as a result of governmental policy and can largely predict who is likely to improve their status over time, and who, no matter their commitment to the destination country, will not ever be able to establish a legal foothold sufficient to allow them to achieve meaningful levels of social and political incorporation. It is these distinct statuses, that, often times, determine an immigrant's or migrant's subsequent chances to live a secure and fulfilling life as well as provide for their family.

Integration refers to policies toward immigrants and migrants regarding employment, housing, health care, education, and civic engagement that are likely to directly affect the path to upward social, economic, and political mobility for these groups. These policies can be distinct from those related to status and can even be contradictory to them. It can also be the case that there is considerable variation between integration policies at national, state/provincial, and local levels of government. Many policies in the above-described issue areas can be more significant in their funding and impact at state/provincial and local levels than they are at the national level. This is certainly the case in the United States where the overwhelming majority of costs regarding education, health care, and social services are paid by state and local governments. It can also be the case that local governments, who have to deal more directly with the consequences of a lack of social and political incorporation, have incentives to think of promoting policies that address integration in ways that are different from officials at national and state/provincial levels. Among the types of integration policies that we can consider are:

- Policies and practices related to employment for immigrant and migrant workers and their families, e.g., whether authorized employment is possible and whether it is restricted to specific sectors of the labor market, specific regions of the country, or for restricted periods of time;

- Policies related to housing for immigrants, migrants, and their families; e.g., whether they have access to publicly subsidized housing, are eligible to purchase housing if they have the financial means to do so, and whether or not housing is restricted to just an authorized worker or also applies to members' of his/her family including children and grandparents;

- Policies and practices related to health care for immigrants, migrants, and their families, e.g., eligibility for medical care, distribution of costs of medical care, access to insurance to cover the costs of health care, and restrictions as to how many times an immigrant, migrant, or family member can utilize medical care;

- Policies and practices related to education for immigrants, migrants, and especially their children, e.g., eligibility of an immigrant or migrant to receive additional education at no cost at a public institution, eligibility of children to attend publicly-funded/subsidized schools in the destination area where a parent may be authorized to work, eligibility of immigrants, migrants, and their children to receive a university education, eligibility of the immigrants, migrants, and their children for financial assistance to attend a university;

- Policies and practices related to civic engagement for immigrants and migrants, e.g., eligibility for voter registration, instruction and assistance in voting when 
an immigrant or migrant is not sufficiently familiar with the host country or area language, and the opportunity to meet with a group to advocate for their interests.

The focus on status and integration pinpoints our analysis to those policy arenas that governmental leaders are in positions to modify to increase levels of social and political incorporation. Although there can be variation across countries in which level of government is primarily responsible for policy enactment and implementation, the focus on status and integration facilitates working toward an alignment of policies across these different levels so that common goals can be achieved. Not surprisingly, such a focus also allows us to begin to specify the incongruities and inconsistencies in policy and practice across different levels of government. Misalignment and inconsistent alignment can be among the major impediments to the more effective social and political incorporation of immigrants and migrants.

\section{Status and integration in the US federal system}

We now use the conceptual categories of status and integration to examine recent developments $^{1}$ and trends in policies toward immigrants in the United States. Unlike many analyses, however, we do not exclusively focus on national policy. We also focus on trends in policies pursued by states that directly affect levels of incorporation.

\subsection{Further attempts at comprehensive immigration reform (CIR)}

The United States national government has been unable to address the fundamental and continuing failures of its immigration policies and practices that have developed over the course of the last several decades. There are currently an estimated 11.7 million unauthorized immigrants in the US today (Passel et al. 2013). The deportation of undocumented immigrants continues to put many immigrant families at risk of being split apart, for example, by the deportation of an immigrant parent, despite their children being full citizens of the United States. There are decades long waits for individuals from many countries, especially Mexico, for those who want to immigrate to the US under current law. There is a backlog of cases to review, some as long as 18 years, for those who have legally applied for US citizenship (Baksh 2011). Most youth who are unauthorized who graduate from high schools in the US and are either interested in enrolling or are currently enrolled in colleges and universities are not eligible for public financial aid. Yet the importance of immigrant labor to the continued stability and growth of the US economy is unquestioned

\footnotetext{
1 We do not attempt a comprehensive categorization and discussion of all policies related to immigrants in the U.S. That is a multi-volume task. We will, however, highlight recent trends in both national and state policies to status and integration as well as the likely impact that continued policies and practices will have on levels of immigrant social and political incorporation.
} 
and is especially apparent in agribusiness, construction, and many areas of low and semi-skill service industries. President Bush called for comprehensive immigration reform in 2004 and the House and Senate were unable to agree on the outlines of revised legislation. Despite the calls by President Obama for comprehensive immigration reform, and despite his recent attempts to reform elements of current deportation policy for youth who came to the US without authorization when they were very young, the House and Senate have still been unable to agree on the outlines of legislation to bring to the President for signature. ${ }^{2}$

Among the most recent attempts to enact comprehensive immigration reform in the US was on June 27, 2013, when a bipartisan group of US senators including Charles Schumer (D-NY), John McCain (R-AZ), Richard Durbin (D-IL), Robert Menendez (D-NJ), Marco Rubio (R-FL), Michael Bennet (D-CO), and Jeff Flake (R-AZ) sponsored Senate Bill 744 entitled the "Border Security, Economic Opportunity, and Immigration Modernization Act of 2013" (US Senate 2013). An examination of the specific provisions of the bill allow us to determine the extent to which status and integration were components of what is considered the most expansive proposal for immigration reform in recent US national politics.

The first section of what has become known as S. 744 is "border security." Border security refers to making it virtually impossible for immigrants to come to the US without authorized status. This section of the Senate proposal contains five specific provisions. One, it is required that the Secretary of the Department of Homeland Security (DHS) develop a comprehensive southern border security plan with a proposed appropriation of $\$ 3 \mathrm{~B}$. Among the most important components of this plan is that the Secretary must show a " $90 \%$ effectiveness rate for apprehensions and returns in high risk border sectors" 6 months prior to any modifications in immigration status for those who are unauthorized. Two, the DHS Secretary must implement a comprehensive system of E-verify for employment, ${ }^{3}$ a fencing plan based on a budget of $\$ 1.5 \mathrm{~B}$, and a biographic entry-exist system at air and seaports before any adjustment in immigration status can begin. ${ }^{4}$ Three, if the $90 \%$ effectiveness goal is not achieved after 5 years, a Southern Border Security Commission was to be established to make recommendations for improvements with a budget of \$2B. Four, to meet the above goals, increases in personnel and budget for the Customs and Border Patrol are allowed as well as authorization for the National Guard to be mobilized. Five, additional resources and training are to be provided to assure that appropriate force is used in apprehensions and that racial profiling is minimized.

The second section addresses legalization for the estimated $11.7 \mathrm{M}$ unauthorized immigrants in the United States. There are many provisions to this section. Among the most important are (1) creating a "Registered Provisional Immigrant (RPI)

\footnotetext{
2 This essay was completed prior to the beginning of the Trump Administration.

${ }^{3}$ E-verify is a system of hiring where only individuals with social security or employment authorization numbers on file with the national government can be hired for any type of work. Violations by either employees or employers could result in fines and/or imprisonment (E-Verify 2014).

${ }^{4}$ It is estimated that $40 \%$ of all persons living in the U.S. without authorized status initially came to the U.S. legally with on a temporary work or tourist visa (Murray 2013).
} 
Program" where persons without authorization who have been in the US continuously since December 31, 2011, can be given RPI status once they pass a criminal background check, proven that they have not been convicted of a serious crime, pay any tax liability and related fees, and pay a \$500 fine; (2) unauthorized farm workers who have worked a minimum of 100 work days or $575 \mathrm{~h}$ in the 2 years prior to the enactment of this legislation will be eligible for an Agricultural Card; (3) an Office of Citizenship and New Americans, the Task Force on New Americans, and the United States Citizenship Foundation are established and will work together to help immigrants learn English, American civics, citizenship responsibilities, and integrate into local communities; (4) a new merit-based system for issuing visas is to be created and based on points for factors such as level of education, employment, family in the US, and length of residence in the US; and (5) spouse and children of lawful permanent residents are allowed to immigrate immediately.

The third provision deals with interior enforcement of immigration laws. Among its major provisions are (1) a 5-year phase in of the E-verify system covering all employers and employees; (2) streamlining of processing for refugee and asylum cases is to occur; (3) increase in immigration court personnel and (4) increases oversight of detention facilities.

The final provision of S. 744 addresses reforms in non-immigrant visa programs and creates new worker visas and increases the ability of those holding such temporary visas to apply for permanent residence. Among the provisions of this component of the law are (1) increasing high skill $\mathrm{H}-1 \mathrm{~B}$ visas for high skill workers from 65,000 to 110,000 per year with an ultimate increase up to 180,000 per year based on a "High Skilled Jobs Demand Index" and work authorization for spouses and children of such visa holders is also allowed; (2) a new agricultural guest worker visa program is proposed allowing for at-will employment-based W-3 visas and contract-based W-2 visas administered by the Department of Agriculture; and (3) creates a new INVEST visa for foreign entrepreneurs who want to come to the US to start their own companies (US Senate 2013).

The provisions of S. 744 make very clear that there is an emphasis on status more than there is an emphasis on integration although both certainly appear. The section on border security is overwhelmingly focused on limiting access by unauthorized immigrants to the US. One can argue that this is certainly within the self-interest of all nations to regulate entry into their countries, however, all of the systematic evidence in the US suggests that those efforts have done relatively little to limit illegal entry over the long-term. In a similar way, the section on interior enforcement also demonstrates an overwhelming focus on status and not on integration.

The section on legalization again focuses significantly on status, however, it also contains various provisions that have direct implications for enhancing the integration of immigrants in employment. This is done by working to assure that authorized status through the category of RPI is provided with a path to permanent residency and ultimately citizenship. However, the length of time to permanent residency is 10 years and the process of naturalization cannot begin for 13 years. Status is enhanced, but it is simultaneously limited for 10 years and then for a total of 13 years before citizenship can be attained. Greater employment eligibility is provided through a clarification of employment status for many categories of 


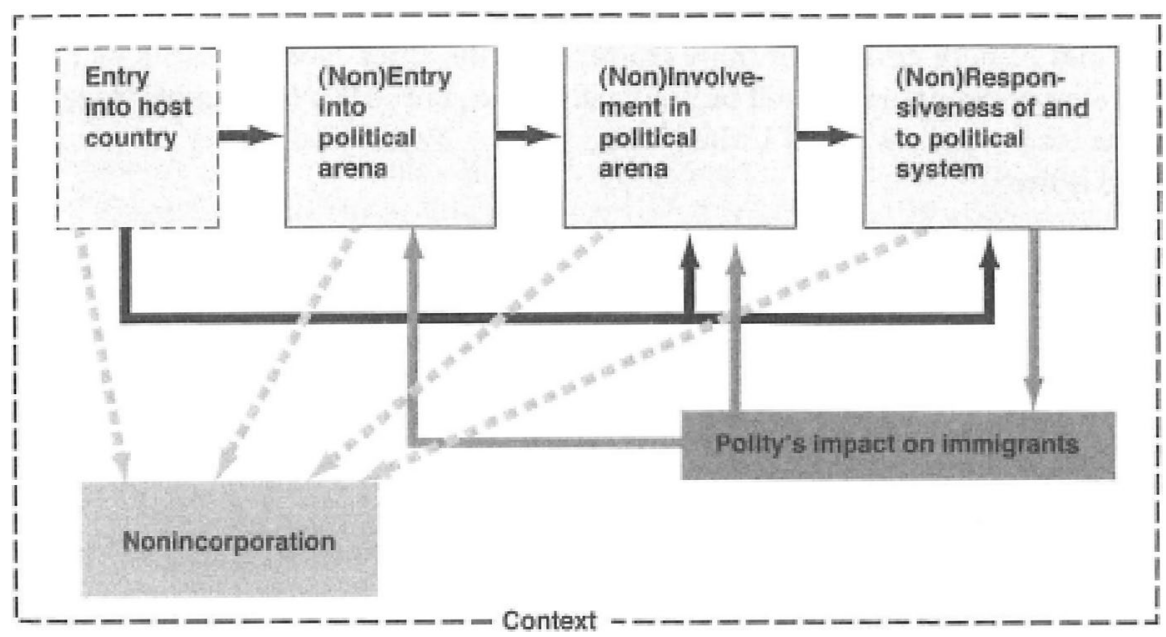

Fig. 3 Full model of immigrant political incorporation. Hochschild and Mollenkopf $(2009,17)$

immigrants. The section on non-immigrant visas focuses overwhelmingly on facilitating employment and investor opportunities.

Only one provision establishing an Office of Citizenship and New Americans, a Task Force on New Americans, and the United States Citizenship Foundation explicitly addresses issues of immigrant integration broadly defined. Interestingly, there is no dollar figure provided for the work of these new agencies and task forces. It is important to note that despite these limitations and lack of clarity as to how immigration integration is to be pursued, this focus on integration is far more apparent than earlier CIR legislation promoted in 2006 and 2007 (Immigration Policy Center 2013). Nonetheless, it must also be noted that there are not explicit provisions allowing legalized immigrants to participate in a formal way in the electoral process. Of course, once naturalization is attained, these individuals would be eligible to register and vote (Fig. 3).

\subsection{Deferred action for childhood arrivals (DACA)}

On June 15, 2012, Janet Napolitano, then Secretary of the Department of Homeland Security announced that her agency was establishing a new category of individuals who would qualify for temporary exemption from the threat of deportation. These individuals were identified as qualifying for deferred action as part of the prosecutorial discretion legally available to the agency in its enforcement of US immigration laws. To qualify for this deferred status a person must be (1) under the age of 31 as of June 15, 2012; (2) come to the United States before reaching their 16th birthday; (3) have continuously resided in the US since June 15, 2007, up to the present time; (4) were physically present in the US on June 15, 2012, and at the time of making the request for deferred action with USCIS; (5) entered without inspection before June 15, 2012, or the person's lawful immigration status expired as of June 15, 2012; 
(6) is currently in school, has graduated or obtained a certificate of completion from high school, have obtained a general education development (GED) certificate, or other equivalent State-authorized examination in the U.S., or is an honorably discharged veteran of the Coast Guard or Armed Forces of the United States; and (7) have not been convicted of a felony, significant misdemeanor, three or more other misdemeanors, or does not otherwise pose a threat to national security or public safety (USCIS 2014).

Individuals who receive deferred status will not be assigned for removal proceedings or will not be removed for 2 years from the United States because of their immigration status. This status can be renewed for an additional 2 years at the end of the first period of deferral. Besides the removal of the immediate threat of deportation, a person with DACA authorization is also authorized to work in the United States for 2 years and can be admitted to institutions of postsecondary education including job training institutes, community colleges, and universities. DACA authorization, however, does not qualify a student pursuing postsecondary education for any type of federal financial assistance. Additionally, DACA authorization is not "lawful status". It is also the case that such authorization does not put a person on the path to permanent residency or citizenship under current US law.

It is again clear that the federal administrative action taken by the Department of Homeland Security at the request of the President of the United States focuses most on status, but also has direct implications for integration. However, the focus on status and integration is only for 2 years with, at present, the possibility for renewal for another 2 years for a total of 4 years. Stated differently, DACA authorization is a temporary move toward greater status and integration for unauthorized youth who were brought to the U.S.

\subsection{The explosion of state policies regarding immigrants}

Among the most significant developments in the recent evolution of immigration policy in the United States is the growth in the number of immigration specific policies enacted by state governments. This is unusual. At least since the 1920's, immigration policy in the US, not surprisingly, has been the exclusive domain of the national government. Its authority over entry and exit visas for tourists, other visitors, and immigrants of all types is well established (Tichenor 2002). It was also during this period of time that there was substantial growth and investment by the federal government in the Immigration and Naturalization Service (INS) and the Border Patrol, its primary agency responsible for enforcement of most immigration laws (Ngai 2003).

However, beginning in the late-2000's many states, including a number of those on the border between the US and Mexico, began to display their dissatisfaction with national government enforcement of immigration laws regarding unauthorized immigrants. They responded by enacting their own laws regarding immigrants and especially regarding those who were in their states who were unauthorized. In a sense, they decided to take immigration policy into their own hands. For example, in 2005 an estimated 300 state bills were introduced that dealt specifically with 
Table 1 Access and integration policies enacted, 2008-2013

\begin{tabular}{lcccc}
\hline Year & Integration & Access & Symbolic & Year Total \\
\hline 2008 & 5 & 2 & 0 & 7 \\
2009 & 142 & 26 & 6 & 174 \\
2010 & 143 & 22 & 138 & 303 \\
2011 & 141 & 35 & 106 & 282 \\
2012 & 104 & 19 & 100 & 223 \\
2013 & 113 & 21 & 252 & 386 \\
Total & 648 & 125 & 602 & 1375 \\
\hline
\end{tabular}

Source: National Conference of State Legislatures (2014). Immigration Enactments Database (2008-2013). http://www.ncsl.org/resea rch/immigration/immigration-laws-database.aspx. Accessed 4.1.14

immigration issues. By 2007 the number of bills introduced grew to 570. In 2008, by contrast, the number grew by almost three times to 1562 . This growth was maintained in the years 2009 and 2010 when the number of immigration related bills introduced in state legislatures were 1500 and 1400 respectively. In these same years, 202 of these proposed bills were enacted into law in 2009, and 208 of those introduced in 2010 were enacted into law by votes of their respective state legislatures and governors (National Conference of State Legislatures 2010).

Table 1 displays the number of state legislative ${ }^{5}$ immigration bills formally enacted into law from 2008 to 2013 categorized by whether their primary impact was related to status or integration and whether the legislation promoted (pro) or limited (anti) status and integration for each of the 50 states in the United States. Bills were coded as related to status if they addressed issues of authorization to live in the Unites States or an individual state. ${ }^{6}$ Bills were coded as related to integration if they had a direct impact on the access that immigrants had to social services and social goods such as jobs, housing, and education. ${ }^{7}$ Bills coded as symbolic referred

\footnotetext{
5 We also include the District of Colombia and the Commonwealth of Puerto Rico.

${ }^{6}$ Examples of such bills regarding status include one that promotes status by allowing someone accused of prostitution to offer as an affirmative defense that they were forced to commit such acts because of the destruction or concealment of a passport or other immigration related document. Examples of bills that limited status are ones that required courts to advise those being tried for a crime that it they entered a plea of guilty, they would be deported from the state to their country of origin and another that required that any person admitted to a state mental hospital who was unauthorized would be reported to the United States Immigration Service for deportation to their home country.

7 Examples of bills that promoted integration include one that provided funding for the increased availability of English language classes and distribution of information regarding naturalization and a bill that required that compensation for work be provided equally to alien nonresidents of the state as it does to residents of the state. Finally, among examples of bills that limited integration are one that required that a person be required to demonstrate proof of legal residency before s/he was permitted to apply for a license through the state board of construction and one that established a seven day, twenty-four hour hotline for anyone to call the state government to report any person or activity related to a suspicion of violation of immigration laws.
} 
directly to immigrants but did so solely by acknowledging immigrants. These bills, however, did not have any substantive impact on either access or integration. ${ }^{8}$

Several patterns that are noteworthy appear in Table 1. First, 2009 represents the first year when a substantial number of laws related to immigration were enacted by state governments. In 2008 only seven total laws were enacted. In 2009 it rose to 174 and it increased to a high of 386 laws in 2013. Second, the smallest number of enacted laws dealt with status. Only 125, a mere $9 \%$ of all 1375 bills enacted during this six-year period related to status. Third, by far the largest number of laws was either symbolic or dealt with integration. Symbolic laws accounted for $44 \%$ of all laws enacted. There were 648 laws, $47 \%$, that directly related to integration. Fourth and most important to our analysis, of the total 773 bills dealing with status or integration, the vast majority, 648, a substantial $84 \%$, dealt with integration. Most state legislation dealt with integration, a traditional area of much state policy-making.

Table 2 displays the data by state for bills that were enacted into law. This means that sufficient consensus was reached within each state legislature and governor to make these laws a part of state policy and practice regarding immigrants. It is apparent that there is quite a bit of variation in the number of bills enacted across the states along both dimensions of status and integration. California and Arizona enacted the largest number of bills related to status at 17, followed by Utah with 16. Most states only enacted a few of bills related to status and a sizeable number enacted none at all. California was the state with the largest number of enacted bills in the area if integration at 73. It was followed by Utah with 36, Illinois with 35, and Virginia with 33. All states except for Alaska and Wyoming enacted at least one. Again, considerable state variation appears.

Figure 4 displays these same data graphically along the two axes of proportion pro-status and pro-integration bills. What is very apparent is that although states are arrayed along the full range of each of these dimensions, clusters of states appear in two primary quadrants, those that are both pro-status and pro-integration and those that are both anti-status and anti-integration. State-level policy making in most states aligns status and integration together, in either a positive or negative dimension. This indicates that state-level policy-making in response to perceived deficiencies in the national government immigration laws in highly uneven, most often contradictory, and confusing. This is also indicated by the bifurcated national averages of pro-status laws at 0.46 and pro-integration laws at 0.52 as indicated in Table 2.

Two states that enacted laws that were both pro-status and pro-integration were California and Florida. Over the time period examined California enacted 15 bills related to status and $14(93 \%)$ of them were pro-status. In terms of integration, 73 bills were enacted and of those $66(90 \%)$ were pro-integration. ${ }^{9}$ Bills enacted in California that were pro-integration included CA S1 in 2010, a part of the omnibus

\footnotetext{
${ }^{8}$ Many of these bills acknowledged contributions made by immigrants or were indications of the sentiment of the legislature without any substantive consequence.

9 Monogan's (2013) analysis of state laws regarding immigration similar scores California as 1.41 on his index. His scores are based on a two-stage analysis of immigration related bills from 2005-2011. He first analyzed bills by their substantive impact (strong to symbolic) and then whether or not the bill was welcoming or hostile. He created an index from -2 (most hostile) to 2 (most welcoming).
} 


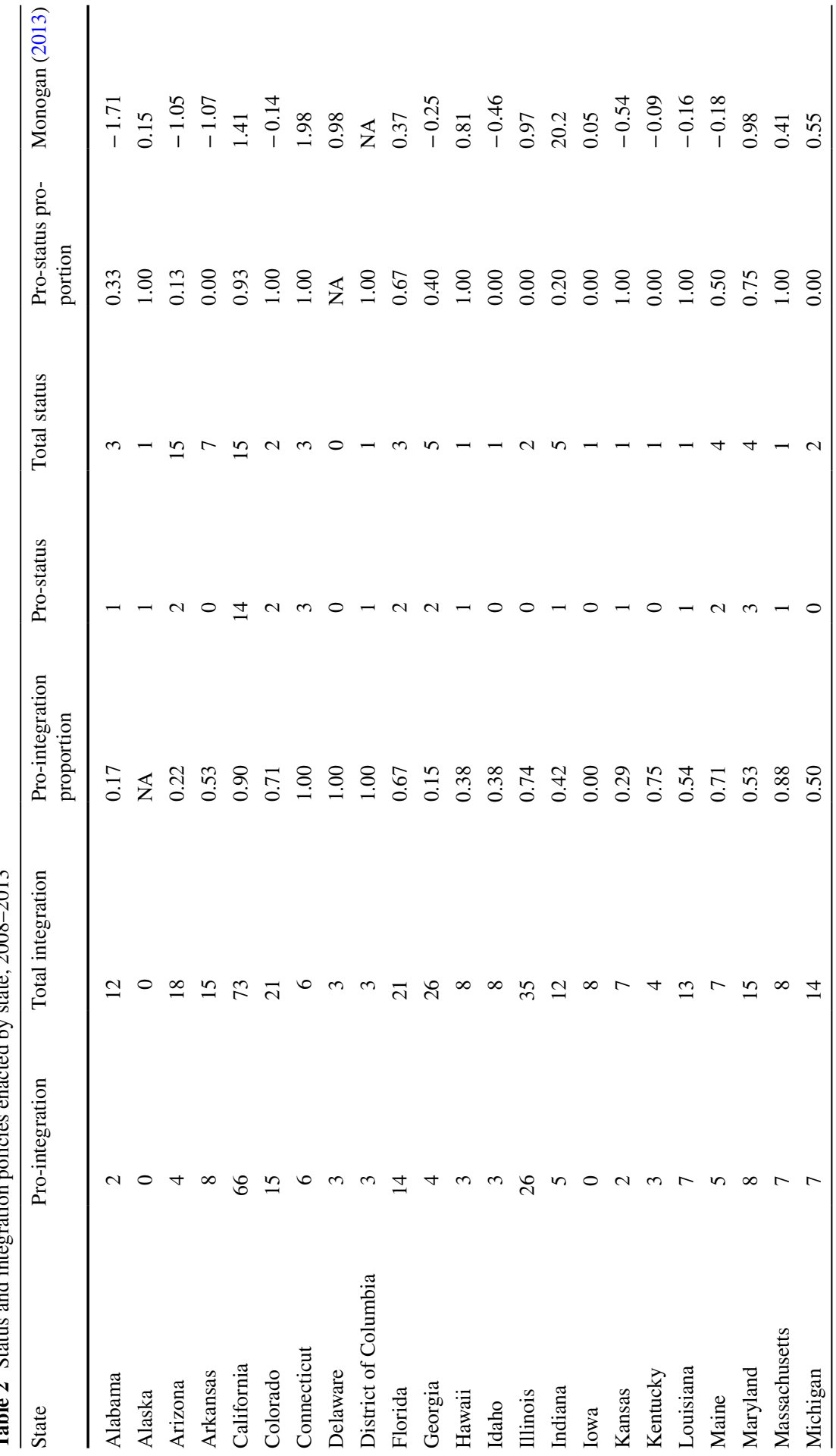




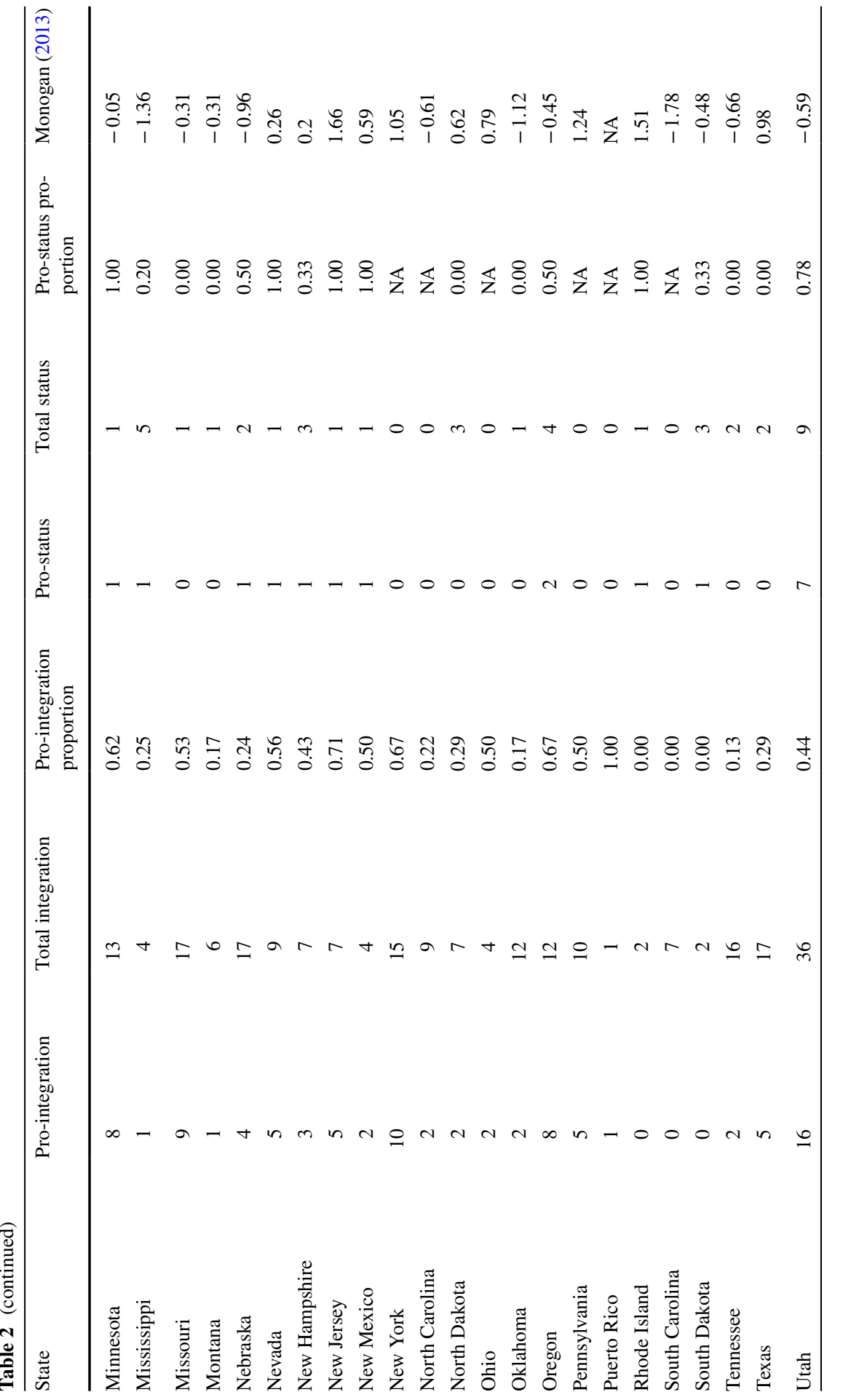




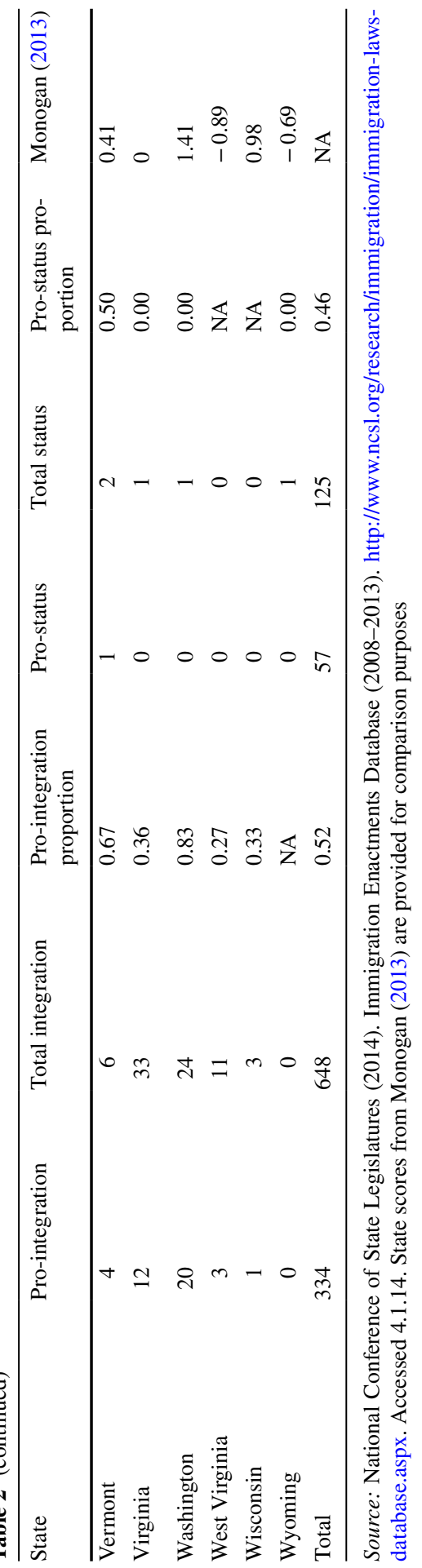




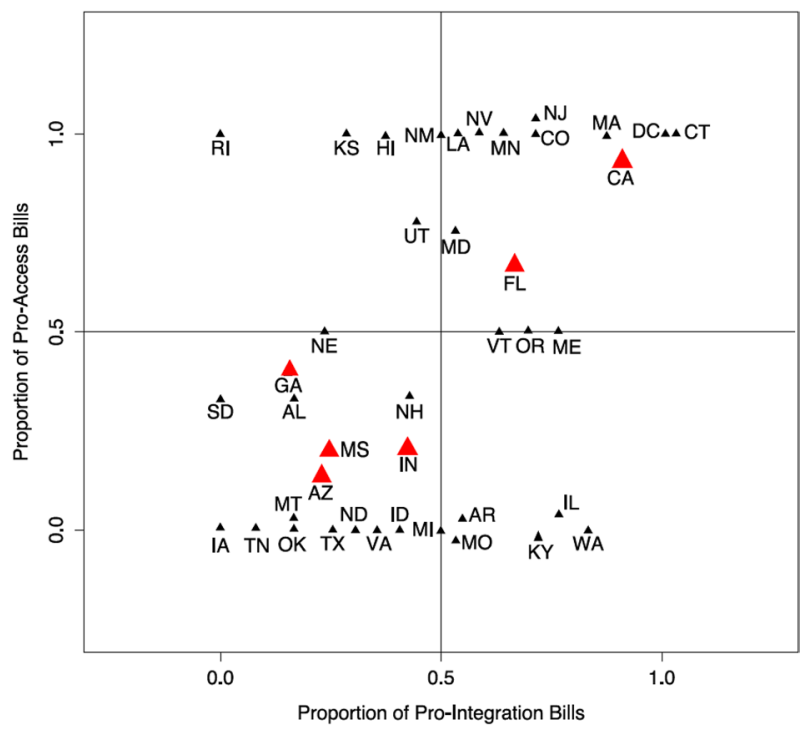

Fig. 4 Status and integration among states, 2008-2013. Source National Conference of State Legislatures (2014). Immigration Enactments Database (2008-2013). http://www.ncsl.org/research/immigration/ immigration-laws-database.aspx. Accessed 1 April 2014

budget bill. Through this bill funding was provided for English language acquisition programs and services for migrants and farm workers. Language acquisition is important for successful integration into the host society (Bloemraad 2006). A second example of a pro-integration law enacted in California is CA A84 in 2011. This law expanded voting options for soon to be naturalized citizens. It allowed individuals who would become legal citizens before election day the opportunity to register before they actually took the oath of allegiance to the US provided they met other requirement establishing residency in the state.

Although more mixed, Florida was another state that enacted a large number of bills related to status and integration. In each area $67 \%$ of the bills were prostatus and $67 \%$ were pro-integration. ${ }^{10}$ In 2012, for example, Florida enacted FL H 1263. This law required that the Florida Department of Health protect migrant farmworkers' living areas. It ensured that basic standards were met for hygiene, sewage removal, pest control, and lightening.

On the other end of the spectrum is the state of Arizona. Between 2008 and 2013, 15 bills were enacted that addressed issues of status and 13,87\%, were anti-status. Similarly, of 18 bills enacted related to integration, $14,78 \%$, were anti-integration. ${ }^{11}$ In 2010, Arizona passed AZ S 1070, which included a number of policy provisions related to both status and integration. The bill included provisions that allowed law

\footnotetext{
10 Mongan (2013) scores Florida 0.37 on his index. This corroborates our findings that while Florida is not as welcoming as states like California, it is significantly more welcoming that hostile.

11 Monogan (2013) scores Arizona a - 1.05 on his index.
} 
enforcement officers, including local police and sheriff's deputies, to detain individuals they suspected of being in the country illegally. These local law enforcement officers were then required to report suspects to the Department of Homeland Security for possible deportation. Some citizens and observers regarded the bill as a hallmark of states' rights and effective governance in a time of economic turmoil. For others it represented a license for discrimination and harassment of Hispanics and other non-Whites. AZ H 2725 also in 2010 was a clear example of anti-integration legislation. This bill increased restricted access to postsecondary education tuition loans, instructional materials, and fees for those pursuing teaching degrees. AZ H 2016, again enacted in 2010, prevented undocumented immigrants from receiving health care services from public entities in the state. It also increased the penalties for those who were found to use fraudulent documents to acquire health related services.

Georgia and Indiana are also cases where state legislatures enacted a greater number of anti-status and anti-integration bills. In the years examined the Georgia legislature successfully enacted 26 integration bills and 22 , a full $85 \%$, were antiintegration. During this same period of time the legislature enacted three (60\%) antistatus bills of a total of five. GA H 119 in 2009 was a general appropriation bill. In it was a provision that gave grants for refugee assistance programs, but at the same time it cut funds for migrant education programs. GA S 20 was an anti-status bill that required work authorization from US Citizenship and Immigration Services for immigrants to obtain drivers licenses and identification cards.

In Indiana, the state legislature enacted 12 integration bills with 7 (58\%) being anti-integration. As an example, in $2011 \mathrm{H} 1402$ does not allow unauthorized Indiana residents to pay in-state resident tuition at public universities. This clearly inhibits the capacity of the DREAMers, discussed earlier, to have a chance of receiving a university education. In that same year the legislature enacted S 590 that, similar to the Arizona's S 1070, expanded the scope of permissible actions by law enforcement agencies with dealing with suspected unauthorized immigrants. In Mississippi the state legislature enacted five bills related to status. Four of them, $80 \%$, were anti-status.

It is clear that many state legislatures are exercising their own authority to respond to perceived deficiencies, both pro- and anti-status, and pro- and anti-integration, in the enforcement of current national laws related to immigration. Again, the unevenness and at times contradictory actions across the states, has produced circumstances in the US where the chances for immigrant's and their families to attain upward social, economic, and political mobility depend just as much on statelevel action as it might on national-level action. Policy alignment between states and the national government in the US regarding the status and integration of immigrants does not occur.

\section{Social rights, immigrants, migrants, and the nation state}

We began this essay by suggesting that there currently exists a disjunction between the interests of immigrants, migrants, and those of nation-states largely due to the policies and practices implemented by governments that often seem to work to limit 
the social rights and incorporation of these groups. By specifying the underlying conceptual frameworks that characterize social rights, social incorporation, political incorporation, status, and integration, we consider how governmental leaders can begin to more clearly outline alternative policies and practices that better align the interests of immigrants and migrants with those of the nation-state and its governmental subdivisions.

Our review and discussion of the frameworks reveals that a series of relationships exists that are dynamic and interdependent, yet clearly related to each other in ways that are highly predictable and subject to public policy intervention. Fundamentally, social incorporation is the foundation of political incorporation and political incorporation can be a necessary condition for the existence of policies that promote greater social incorporation. More specifically, policies related to status are the necessary foundation for the achievement of greater levels of integration. Where public policy decision-makers need to focus their efforts if they want immigrants and migrants to become full and contributing members of the nation-state is not a mystery.

In our view, the opportunity for governmental decision-makers to pursue such policies that facilitate social integration is the same in countries with distinct processes of policy decision-making. The enactment of such policies in the US has been constrained by the perceived electoral gains of more conservative Republican law makers who understand anti-immigrant positions to be the preference of many of their electoral supporters.

Our empirical examination of recent policy proposals and laws enacted in the United States at both national and state levels with the conceptual categories of access and integration reveals the continuing challenges this country faces in deciding whether it can pursue policies that will promote social rights and greater social and political incorporation. Recently, one of the most comprehensive proposals at the national level for comprehensive immigration reform must, for political purposes, be grounded in clear statements regarding limiting access through enhanced border security. Although enhanced integration is also a goal of some elements of the proposed legislation, they are all predicated on first limiting the access that future immigrants have to authorized status in the United States. It is evident that the political realities of having any chance of securing the necessary bipartisan support to enact any national legislation that might serve the interests of many current unauthorized immigrants to the United States (see Fraga 2009), requires limiting access to many potential future immigrants. Our review of recent laws enacted by state governments demonstrates that limiting access is similarly a focus of attention of states and that limiting integration is characteristic of an overwhelming majority of laws enacted that directly limits the integration of immigrants. The prospects of greater social and political incorporation of immigrants in the United States are, at present, quite limited.

Interestingly, policy decision-makers in China may have more autonomy to enact policies that facilitate social integration for its migrant populations. In China, the interests of local, provincial, and the national governments to promote predictability, social stability, and economic growth can serve as very useful justification for the pursuit of policies that facilitate social integration for migrants. 
This is not to say that there cannot be opposition to such policies by some competing interests. However, Chinese government officials have the opportunity to consider long-term implications in ways that do not exist in the United States.

Moreover, although there is variation across provinces and local governments in China regarding the social rights of migrants that can directly affect the process and pace of migrant social integration, it is not uncommon for the national government to intentionally seek to collaborate with provincial and local government leaders to enact policies that are designed to serve the long-term interests of the nation-state. It is this capacity to find common ground across levels of government that, as we indicate in our empirical examination of immigrant integration laws in the US, is one of the perpetual limits to the capacity of immigrants in the US to attain social integration. China's history of placing the interests of the nation-state at the forefront of much of its policy making may make enacting policies of migrant integration more possible across all levels of government.

The attainment of full and meaningful social rights by immigrants and migrants present nation-states with the chance to build communities of increased mobility, enhanced economic growth, and more long-lasting social stability. It is difficult to see how barriers placed to greater social and political incorporation, by limiting access and integration, serve the long-term interest of any nationstate, however much it may serve the short-term interests of government officials by responding within the parameters of contemporary politics. It is likely to be the case that those nation-states who are led by officials willing to take the long view of the country's interests, across all levels of government, will be the ones characterized by sustained economic growth and social stability.

\section{References}

Alba, R. D., \& Nee, V. (2005). Remaking the American Mainstream: Assimilation and Contemporary Immigration. Cambridge: Harvard University Press.

Baksh, S. (2011). How Long Do Immigrant Families Wait In Line? Sometimes Decades. Colorlines News for Action. http://colorlines.com/archives/2011/07/visa.html. Accessed 21 Oct 2014.

Bloemraad, I. (2006). Becoming a Citizen: Incorporating Immigrants and Refugees in the United States and Canada. Berkeley: University of California Press.

DeSipio, L. (2011). Immigrant Incorporation in an Era of Weak Civic Institutions: Immigrant Civic and Political Participation in the United States. American Behavioral Scientist, 55(9), 1189-1213.

E-Verify. (2014). U.S. Citizenship and Immigration Services. Department of Homeland Security. http:// www.uscis.gov/e-verify. Accessed 21 Oct 2014.

Fraga, L.R. (2009). Building Through Exclusion: Anti-Immigrant Politics in the United States. In J.L. Hoschschild, J.H. Mollenkopf (Eds.), Bringing Outsiders In: TransAtlantic Perspectives on Immigrant Political Incorporation (pp. 176-192). Ithaca, NY: Cornell University Press.

Freeman, G. P. (2004). Immigrant Incorporation in Western Democracies. International Migration Review., 38(3), 945-969.

García-Castañon, M. (2013). Theory of Multi-Tiered Membership. Ph.D. dissertation, University of Washington.

Immigration Policy Center. (2013). A Guide to S. 744. Understanding the 2013 Senate Immigration Bill. http://www.immigrationpolicy.org/special-reports/guide-s744-understanding-2013-senate-immig ration-bill. Accessed 15 March 2014. 
Hochschild JL., Mollenkopf JH (2009) Modeling Immigrant Political Incorporation. In J.L. Hoschschild, J.H. Mollenkopf (Eds.), Bringing Outsiders In: TransAtlantic Perspectives on Immigrant Political Incorporation (pp. 15-47). Ithaca: Cornell University Press.

Itzigsohn, J., \& Giorguli-Saucedo, S. (2005). Incorporation, Transnationalism, and Gender: Immigrant Incorporation and Transnational Participation as Gendered Processes. International Migration Review, 39(4), 895-920.

Lee, T., Ramakrishnan, S. K., \& Ramiìrez, R. (Eds.). (2006). Transforming Politics, Transforming America: The Political and Civic Incorporation of Immigrants in the United States. Charlottesville: University of Virginia Press.

Marrow, H. B. (2011). New Destination Dreaming: Immigration, Race, and Legal Status in the Rural American South. Stanford: Stanford University Press.

Monogan, J. E. (2013). The Politics of Immigrant Policy in the 50 U.S. States, 2005-2011. Journal of Public Policy, 33(1), 35-64.

Murray, S. (2013). Many in US Illegally Over Stayed Their Visas. Wall Street Journal. http://onlin e.wsj.com/articles/SB10001424127887323916304578404960101110032. Accessed 21 Oct 2014.

National Conference of State Legislatures. (2010). State Legislative Data Base. Immigration Bills.

Ngai, M. (2003). Impossible Subjects: Illegal Aliens and the Making of Modern America. Princeton: Princeton University Press.

Passel, J.S., Cohn, D., Gonzalez-Barrera, A. (2013). Population Decline of Unauthorized Immigrants Stalls, May Have Reversed. Pew Research Hispanic Trends Project. Washington, DC: Pew Research Center.

Portes, A., \& Bach, R. L. (1985). Latin Journey: A Longitudinal Study of Cuban and Mexican Immigrations to the United States. Berkeley: University of California Press.

Portes, A., \& Borocz, J. (1989). Contemporary Immigration: Theoretical Perspectices on Its Determinants and Modes of Incorporation”. International Migration Review, 23(3), 606-630.

Portes, A., \& Rumbaut, R. G. (2006). Legacies: The Story of the Immigrant Second Generation. Berkeley: University of California Press.

Ramírez R, Fraga LR. (2008). Continuity and Change: Latino Political Incorporation in California since 2009. In B. Cain, J. Regalado, S. Bass (Eds.), Racial and Ethnic Politics in California, vol. 3 (pp. 61-93). Berkeley: Berkeley Public Policy Press.

Telles, E. (2010). Mexican Americans and Immigrant Incorporation. Contexts, 9(1), 28-33.

Tichenor, D. (2002). Dividing Lines: The Politics of Immigration Control in America. Princeton: Princeton University Press.

United States Custom and Immigration Service (USCIS). (2014). Consideration of Deferred Action for Childhood Arrivals Process. http://www.uscis.gov/humanitarian/consideration-deferred-actio n-childhood-arrivals-process. Accessed 15 March 2014.

US Senate. (2013). Border Security, Economic Opportunity, and Immigration Modernization Act of 2013. S. 744. Proposed legislation. (https://www.govtrack.us/congress/bills/113/s744/text. Accessed 15 March 2014.

Zolberg, A., \& Woon, L. L. (1999). Why Islam Is Like spanish: Cultural Incorporation in Europe and the United States. Politics and Society, 27(1), 5-38.

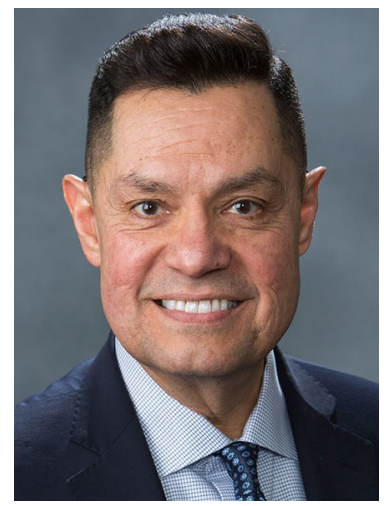

Luis Ricardo Fraga is the Rev. Donald P. McNeill, C.S.C., Professor of Transformative Latino Leadership, Joseph and Elizabeth Robbie Professor of Political Science, Director of the Institute for Latino Studies, and Acting Chair of the Department of Political Science at the University of Notre Dame. He is the author and coauthor of five books including Latinos in the New Millennium: An Almanac of Opinion, Behavior, and Policy Preferences (Cambridge University Press 2012). He has also published over forty journal articles and book chapters including in the American Political Science Review, American Journal of Political Science, Journal of Politics, and Perspectives on Politics. 


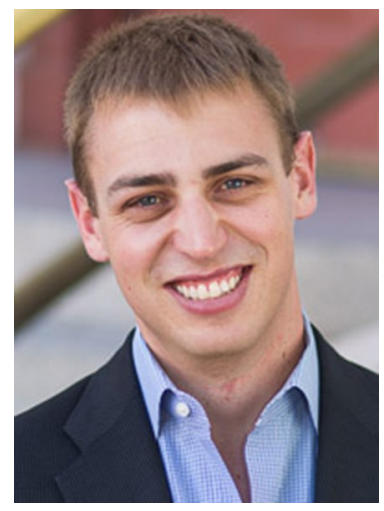

Bryan Wilcox-Archuleta is a Ph.D. candidate in Political Science and M.S. candidate in Statistics at the University of California, Los Angeles. He received undergraduate degrees from The University of New Mexico and a graduate degree from the University of Washington. His research explores connections between context and group based identities among racial and ethnic minority groups in the U.S. His work appears in Political Research Quarterly, Journal of Race, Ethnicity, and Politics, and Research and Politics. He can be reached at bwa@ucla.edu or http://www.bryanmwilcox.com/. 